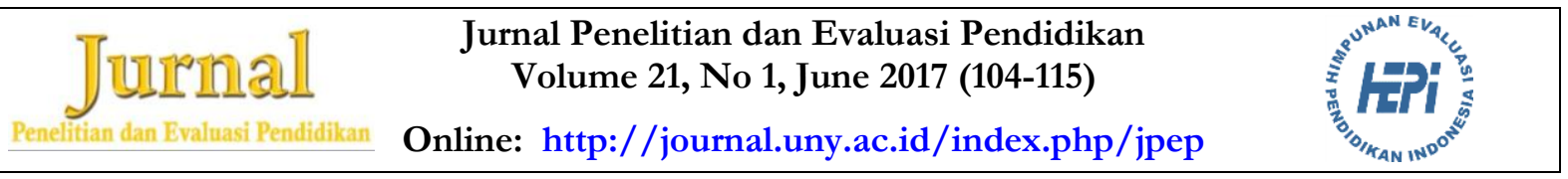

\title{
THE EVALUATION OF AUTHENTIC ASSESSMENT IMPLEMENTATION OF CURRICULUM 2013 IN ELEMENTARY SCHOOL
}

\author{
Muhammad Nur Wangid ${ }^{*}$, Ali Mustadi ${ }^{1}$, Anwar Senen ${ }^{1}$, Nur Luthfi Rizqa Herianingtyas ${ }^{1}$ \\ ${ }^{1}$ Universitas Negeri Yogyakarta \\ ${ }^{1}$ Jl. Colombo No. 1, Depok, Sleman 55281, Yogyakarta, Indonesia \\ *Corresponding Author. Email: m_nurwangid@uny.ac.id
}

\begin{abstract}
This research was aimed to evaluate the implementation of authentic assessment of elementary school in Province of Yogyakarta and also to know the obstacles of its implementation. This was an evaluative research by a Stake's evaluation model approach. The results of observation in compare to the standard of assessment should be criteria to determine the succeed. This research subjects were elementary teachers in Province of Yogyakarta. Observation, interview, and documentation were used to gather data. The research showed that: (1) Planning (antecedents) stage or understanding towards authentic assessment planning has not been fulfilled the standard to be categorized as Good with percentage of $68.75 \%$; (2) Process (transaction) or implementation stage that obtained $63.41 \%$ in percentage was classified in Good category; (3) Outcome stage or authentic assessment report showed $68.48 \%$ in percentage and should be categorized Good. The implementation of authentic assessment in Province of Yogyakarta elementary schools have not 100\% met the standard. Therefore, results from this research finding were expected to be tools to improve performance from all stakeholders.
\end{abstract}

Keywords: authentic assessment evaluation, Curriculum of 2013

Permalink/DOI: http:/ / dx.doi.org/10.21831/pep.v21i1.15779 


\section{Introduction}

Curriculum of 2013 comes with a new color in the world of education in Indonesia. Its dynamic and revolutionarily character make a fundamental transformation in the practices, for instance is an emergence of the paradigm of authentic assessment as the basis of assessment in teaching practice. The assignment is based on the reflection of the humanist that represents the result of human learning is not only in terms of cognition, but also there are some sides which involved in it; which are affective and psychomotor, therefore, in regards to see learning outcomes, student cannot be seen only by single variable, thus education should be able to become a place as well as a tool that can reflect the ability of each individual to learn from various authentic sides.

Authentic assessment in the Curriculum of 2013 refers to regulation of Ministry of Culture and Education No. 66 Yeaer 2013 on the Standards for Educational Assessment (Mendikbud RI, 2013), which is a process of collecting, reporting and use of information about student learning outcomes by applying the principles of assessment, implementation of sustainable, authentic evidences, accurate, and consistent as public accountability. The aim is to plan an assessment that suitable with the achieveable competence and based on the principles of assessment, professional, open, educative, effective, efficient, and in line with the social and cultural context; and reported the results in an objective, accountable, and informative way.

The term authentic derived from synonyms of original, real or true so that authentic assessment is often described as an assessment of the fact of the development of learners that viewed from different sides and competences, which in this case includes three domains of learning process which are manner, skills, and knowledge. Hein (1991, p. 116) gives a perspective that, "through authentic assessment we can assess students in a variety of ways: we can observe what they do, listen to what they say, read what they write, and analyze what they produce. Any behavior that can be perceived can be adapted for assessment". A teacher can find out the ability of students through a variety of assessment strategies as well as reflects the learning process that has been implemented. Fook \& Sidhu (2010, p. 154) imply that "authentic assessment emphasizes the practical application of tasks in real-world settings". It means that an authentic assessment is not only measure students' theoretical ability but rather the application of their skill and manner. Thus the student achievement is represented by the ability to practice not only memorizing study materials. Mueller (2005, p. 5) defines, "authentic assessments as direct measure of students' acquired knowledge and skills throughformal education to perform authentic tasks. Therealistic contexts can make problems more engaging forstudents and help the teachers evaluate whether astudent who can solve a problem in one context cantransfer the skills to a similar setting." Authentic assessment is able to directly measure how far the knowledge, skills and manner can be applied by students in solving practical problems in their daily life. Furthermore, Palm (2008) describes that "authentic assessment is what claimed in or by the task or assessment is really true. The fact that something is supposed to be true, however, gives the concept different meanings depending on the chosen frame of reference. The meaning of the word authentic makes the choice of focus an open question, and different foci have also been applied in the literature. Two main issues are of interest here: what it is that is supposed to be real or true, and what it is that it is supposed to be true to." It can be interpreted that authentic assessment is the correct assessment and in accordance with the facts. The meaning of word authentic lead us to the open, relevant, and right questions. Wiggins (1989, p. 41) describes four characteristics of authentic assessment among others: (1) The task should be representative of performance in the field, (2) Attention should be paid to teaching and 
learning the criteria for assessment, (3) Selfassessment should play a great role, (4) When possible, students should present their work publicly and defend it. Thus, representatively this kind of assessment assesses the process and outcome of students learning process. Additionally, in a separate article, Wiggins (1989a, p. 711) emphasized the importance of contextual student homework as a part of the authentic assessment such as creating a report paper to enforce student to collaborate with their friends.

Ministry of Culture and Education (2014) in this context mentioned that authentic assessment is a significant meaningful measurement to the student's result of study in terms of manner, skills, and knowledge. It is known that authentic assessment may reflect aspects of affective, psychomotor, and cognitive that found in the students' learning activities. Thus, authentic assessment requires students to show manner, using the knowledge and skills gained from learning in the conduct of the actual situation. Authentic assessment carried out com-prehensively to assess the input, process, and output of learning, including manner, knowledge, and skills. Authentic assessment is aimed to measure student's knowledge, skills and attitudes in a valid and concrete way. To assess those three aspects, there are various types of assessment that can be done, Ministry of Culture and Education (2014) mentioned the types of authentic assessment as follows: (1) performance evaluation consist of: $\log$ and learning journal; structured assignment; task performance; long-term projects; portfolio; demonstration; experiment; presentation; and simulation, (2) project assessment, (3) portfolio (4) written assessment, and (5) attitude. Forms of authentic assessment to assess student's manner competence, such as: (1) oservation; (2) self-assessment; (3) peer-assessment; and (4) journal assessment, meanwhile the aspects of assessment for knowledge competencies include: (1) written test; (2) discussion observation-question and answer, and conversation; and (3) assignments. The form of assessment for skill competence are: (1) performance assessment; (2) project assessment; (3) product assessment; and (4) portfolio assessment.

As an integral part of learning process, it is important to design and apply an assessment systematically, this refers to the necessity of teachers to know the mechanisms, procedures and instruments of student learning outcomes assessment in accordance with the competencies to be measured. Competence as measured through authentic assessment describes the demands that exist in the Standard of Competence or Core Competence, and the Basic Competencies. The focus of assessment in Curriculum of 2013 was the success of students in achieving competency standards as specified, including manner, skills, and knowledge. Therefore, teachers must pay attention to the attainment of students to ensure they are measured empirically by the standard and achieve the purpose of learning. Authentic assessment is also need to give a picture about student's development right after the learning process, this refers to the necessity of teachers to do perpetual and comprehend assessment, it means that teachers should understand the development of their student everyday, authentic assessment is not only seeing the result but also the process behind that to be a consideration in the assessment process itself.

Teachers in this case play a role as an evaluator of learning, have the ideal capacity and are able to understand and implement authentic assessment in a professional manner in accordance with what required in Curriculum of 2013. But in fact, since second year of Curriculum 2013, the implementation of authentic assessment still be one of the main evaluation issue due to the obstacles in its implementation, it implies by the results of a questionnaire given to 100 teachers grade 5 in Yogyakarta, the result shows that $100 \%$ of the respondents think there are obstacles in implementing authentic assessment. In addition, a survey conducted by Khilmiyah, Sumarno, \& Zuchdi $(2015$, p. 2) found that $70 \%$ of intelligence and judgment that has been de- 
veloped in elementary school around Yogyakarta is through cognitive assessment. Teacher's attention and understanding to the importance of development of emotional, social, and spiritual intelligence is still low in the learning and assessment process. Assessment of the student's character is only based on teacher's observations during school day. It means that authentic assessment that includes cognitive, affective, and psychomotor aspects has not been applied optimally. In regards to that problem, to know more about the obstacles and problems we need to evaluate the implementation of authentic assessment, especially to elementary teachers in Province of Yogyakarta. Arikunto (2013, p. 325) argues that the evaluation of a program is a series of activities and it is purposes to see how far the program is succeed. According to Sukmadinata (2009, p. 172), evaluation and curriculum have a causal relationship where a change in the curriculum will influence the curriculum evaluation and curriculum evaluation would otherwise change the aspects of curriculum implementation. The evaluation is purposes to find out the lacks so that it can be a consideration in the future implementation of education system. The results of evaluation curriculum can be used by teachers, principals and other educational stakeholders. In line with the aforementioned opinion, Doll (1964, p. 22) says that "Acknowledge presence of value and valuing, orientation to goal, comprehensiveness, continuity, diagnostic worth and validity and integration." An evaluation and assessment should contain value and assessment, has a clear purpose or objective, comprehensive and perpetual, has a function as diagnostic tool, and integrated. Hence, the evaluation was not carried out randomly, but systematic, detailed and use procedures that have been tested thoroughly. Furthermore, Alkin (2011, p. 10) also states that "a definition of evaluation based on its goal. Evaluation is the favored term when we talk of judging a program," it implies that evaluation is an activity to gather information about how the program runs, which is used to determine future action to be done.

Evaluation model used in this study is a stake model, which is one of the educational system of evaluation models. Stake emphasizes on implementation of the two main aspects, namely (1) description and (2) consideration (judgments), and distinguishes three stages in the evaluation of the program, which are (1) antecendents/context, (2) transaction/process, and (3) output-outcomes. According to that, this study aimed to find out the implementation of authentic assessment in elementary school in Province of Yogyakarta and also to know about the obstacles of its implementation.

\section{Methods}

This is an evaluative research that aimed to evaluate the implementation of authentic assessment of Curriculum 2013 in elementary school of Province of Yogyakarta. The result of evaluation is expected to be a base or foundation to measure the achievement of curriculum assessment in 2013 and also to give judgement or recommendation in regards to improve the quality of its implementation. Evaluation approach that be used in this study is Stake's Countenance Model that measure the implementation of authentic assessment with the standard of that should be a criteria to determine the succeed. Stake model design's evaluation emphasized two major aspects which are description and judgement. Those two major aspects is distinguished into three stages of evaluation, as follow: (1) input and planning (antecedent), (2) process (transaction), (3) outcomes. Stake model is a systematic method to evaluate the overall implementation of authentic assessment process that includes planning, implementation, and assessment. We choose Stake model of evaluation with the consideration that we would like to conduct and focus on evaluation of the implementation of authentic assessment. Evaluation design with this model has several stages, such as: (a) antecedent phase that describes teacher's experience on the design of authentic as- 
sessment (knowledge, skills, and manner), (b) transaction phase, describes implementation of authentic assessment, (c) output phase, describes assessment's result management. Furthermore, the authors made the judgement pertaining to stakeholder's understanding on authentic assessment implementation in elementary school in Province of Yogyakarta. Our decision were based on two thing: (1) absolute standard, which explain on the existing process, and (2) relative standard that put the base on standard or criteria which is in line with authentic assessment program. The authors will relate its relevance to the congruence between what is intended and observed. We observed 63 elementary schools that has already applied Curriculum of 2013 in Province of Yogyakarta since August 2016 and we finish this study in October 2016. The study's populations are teachers. To determine the sample we use an equation from Issac and Michael (Sukardi, 2011, p. 55) as follow:

$$
S=\frac{X^{2} \cdot N \cdot P(1-P)}{d^{2}(N-1)+X^{2} P(1-P)}
$$

Information:

$\mathrm{S}=$ Number of sample

$\mathrm{N}=$ Total Populations

$\mathrm{P}=$ The proportion of population as a basic assumption of table creation. This price is taken at $\mathrm{P}=0.50$.

$\mathrm{d}=$ Degree of accuracy reflected by an error that can be tolerated in the $\mathrm{P}$ sample fluctuation, $\mathrm{d}$ is generally taken at 0.05 .

$\mathrm{X} 2=$ Value of chi-square table for one degree of relative liberation desired confidence level. X2 = 3.841 confidence level of 0.95 .

The results of sample enumeration from 60 fourth grade teacher with a error sampling of $5 \%$ obtained a sample of 18 fourth grade of elementary school teachers. However, in this study we used a sample of 20 teachers. This is a descriptive evaluation study which aims to provide an overview of reality in the implementation of authentic assessment in Curriculum 2013 by having a theoretical concept that has been developed towards aspects that will be evaluated. All the data were analyzed using percentage analysis techniques then described and drawn conclusions about each of the components on the basis of predetermined criteria. The amount of the percentage in each category shows the information disclosed directly and the position of each aspect of whole or parts of the problems studied can be seen. Data were analyzed using an inter-active model of (Miles, Huberman, \& Saldana (2014, p. 12), which consists of data collection, display, and conclusion. While quantitative data on the results of observations were analyzed using percentage analysis.

\section{Results and Discussion}

Result

Study of evaluation in implementation of authentic assessment in elementary school in Province of Yogyakarta conducted based on description and judgement principles. Both are obtained through the depiction of the preliminary stage (antecedent), stage of the process (transaction), and the results (outcomes). Data obtained in this study can be divided into three parts, namely the input and planning (Antecedent phase), process/implementation (Transaction phase), and results/evaluation (Outcomes phase). At each stages will be compliance (horizontally) between planning (intents) and the data obtained from the results of the implementation of the observations (observations). If there is a discrepancy, then there will be consideration/suggestions/feedback on the implementation of authentic assessment that suitable with the real condition. Furthermore, we will monitor if there is discrepancy at each stages. Further analysis to look for suitability (congruence) between the expected implementation of authentic assessment (intended) in accordance with the standards observed at each stages. The results are shown in Table 1. 
Table 1. Data Evaluation Authentic Assessment

\begin{tabular}{|c|c|c|c|c|c|}
\hline \multirow{2}{*}{ Stage } & \multirow{2}{*}{ Aspect } & \multirow{2}{*}{ Percentage } & \multirow{2}{*}{ Category } & \multicolumn{2}{|r|}{ Judgment Matrix } \\
\hline & & & & Standard & Judgments \\
\hline \multirow{3}{*}{$\begin{array}{l}\text { Input } \\
\text { (Atencedents) }\end{array}$} & Manner & $63.99 \%$ & B & $100 \%$ & $\begin{array}{l}\text { Yet need to be given } \\
\text { appropriate consideration }\end{array}$ \\
\hline & Skills & $71.06 \%$ & B & $100 \%$ & $\begin{array}{l}\text { Yet need to be given } \\
\text { appropriate consideration }\end{array}$ \\
\hline & Knowledge & $71.25 \%$ & B & $100 \%$ & $\begin{array}{l}\text { Yet need to be given } \\
\text { appropriate consideration }\end{array}$ \\
\hline \multirow{3}{*}{$\begin{array}{l}\text { Process } \\
\text { (Transaction) }\end{array}$} & Manner & $43.42 \%$ & $\mathrm{C}$ & $100 \%$ & $\begin{array}{l}\text { Yet need to be given } \\
\text { appropriate consideration }\end{array}$ \\
\hline & Skills & $61.88 \%$ & B & $100 \%$ & $\begin{array}{l}\text { Yet need to be given } \\
\text { appropriate consideration }\end{array}$ \\
\hline & Knowledge & $84.96 \%$ & B & $100 \%$ & $\begin{array}{l}\text { Yet need to be given } \\
\text { appropriate consideration }\end{array}$ \\
\hline \multirow{3}{*}{$\begin{array}{l}\text { result } \\
\text { itcome) }\end{array}$} & Manner & $54.76 \%$ & $\mathrm{C}$ & $100 \%$ & $\begin{array}{l}\text { Yet need to be given } \\
\text { appropriate consideration }\end{array}$ \\
\hline & Skills & $70.97 \%$ & B & $100 \%$ & $\begin{array}{l}\text { Yet need to be given } \\
\text { appropriate consideration }\end{array}$ \\
\hline & Knowledge & $80.08 \%$ & B & $100 \%$ & $\begin{array}{l}\text { Yet need to be given } \\
\text { appropriate consideration }\end{array}$ \\
\hline
\end{tabular}

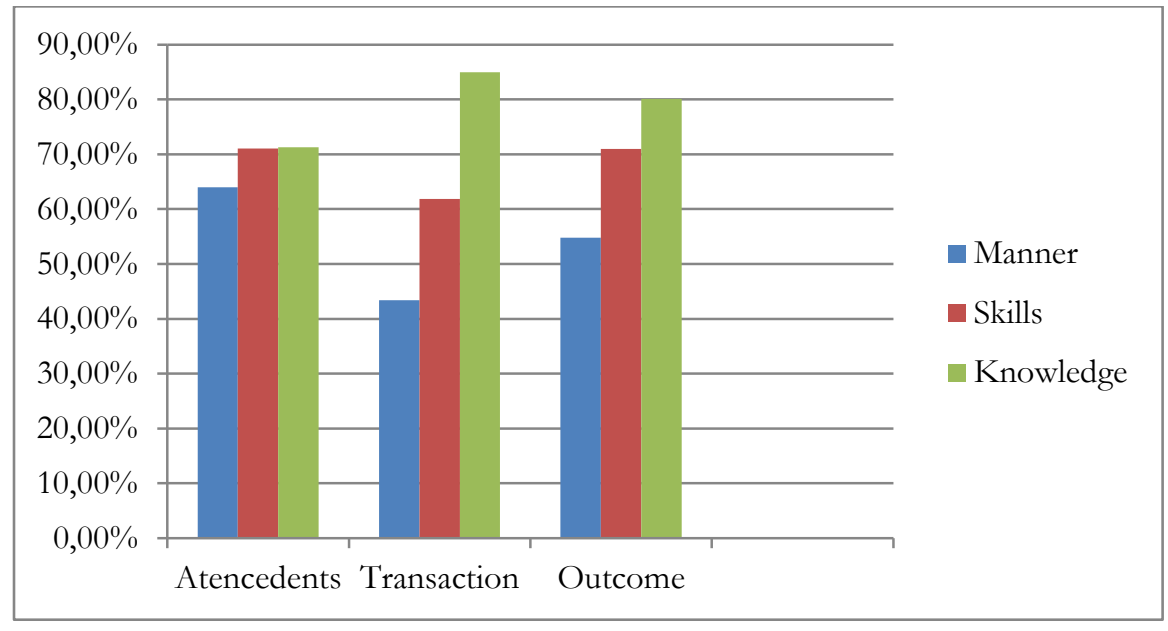

Figure 1. Implementation of Authentic Assessment at Every Stages

At the input or planning stages, known that assesses on the manner are still not optimal in the amount of $63.99 \%$, which is only categorized in Good level, the results imply that the assessing plan on the manner do not meet with the standard required. Parameter of skills is also do not implemented optimally with $71.06 \%$ of percentage and placed in Good category.
Meanwhile the knowledge parameter have $71.25 \%$ in percentage and do also categorized as Good and still need some considerations. At this stage of the process or implementation, the lowest percentage is $43.42 \%$ and categorized as Enough, it indicates that most of teachers do not apply proper manner assessment in learning process, in addition to the implementation of 
the skills assessment is also only reached $61.88 \%$ of percentage and still need to get feedbacks and improvements. Aspects of knowledge get the highest percentage compared with other aspects which reached $84.96 \%$, it means the teacher has been able to carry out an assessment of knowledge well although not optimal. In the output stage, known that manner assessment is still very low which is only at the $54.76 \%$ of percentage, skills in $70.97 \%$, and knowledge assessment is in $80.08 \%$. Those aspects still need further considerations.

Implementation of authentic assessment can be seen from diagram in Figure 1.

Furthermore, the results of these evaluations are systematically processed with Stake model evaluation (Stake's Countenance Model), which measures the enforceability of authentic assessment on the Curriculum 2013. Stake's model evaluation design emphasizes the implementation of the two major things which are description and consideration of the decisions (judgments). The following chart is presented according to the Stake's Countenance Model in the Table 2.

From that chart we can analyze vertically the antecedent stage (planning), tran- saction (process), and outcomes (results). At the expected conditions, the third stage has a percentage of $100 \%$, means that there are no gaps between the three stages. But in actual conditions (observed), there is a gap between the percentage of the third stage. There is a gap between antecedent (preliminary) and transaction (process). Antecedent transaction amounted to $68.75 \%$ and amounted to $63.41 \%$. From these two stages, there was a decrease of $5.34 \%$. That is at the planning stage teachers already planed well although there are still shortcomings in the implementation, meaning that not all of the plan can be implemented by teachers appropriately. Gaps also occured between transaction (process) and outcomes (results). Transaction (process) have $63.41 \%$ of percentage, while outcomes (results) are in $68.48 \%$. The gap at second stage is an increase of $4.07 \%$. This means that although the process of implementation of authentic assessment is not optimal but teachers are already understand how to make a report on authentic assessment. However, it still need a lot of feedbacks and considerations.

Table 2. Results of Evaluation Model Stake

\begin{tabular}{|c|c|c|c|}
\hline \multicolumn{2}{|l|}{ The Expected Conditions } & & \multirow[t]{2}{*}{ Actual state (observed) } \\
\hline Antecedent & & & \\
\hline $\begin{array}{l}\text { Understanding of the design } \\
\text { of authentic assessment }\end{array}$ & $100 \%$ & $\leftarrow$ Conformity & $68.75 \%$ \\
\hline Discrepancy & & & Discrepancy \\
\hline Transaction & & Conformity & \multirow[b]{2}{*}{$63.41 \%$} \\
\hline $\begin{array}{l}\text { Implementation of authentic } \\
\text { assessment }\end{array}$ & $100 \%$ & $\leftarrow$ & \\
\hline Discrepancy & & & Discrepancy \\
\hline Outcomes & & Conformity & \multirow[b]{2}{*}{$68.48 \%$} \\
\hline $\begin{array}{l}\text { Reporting the results of an } \\
\text { authentic assessment }\end{array}$ & $100 \%$ & $\leftarrow$ & \\
\hline
\end{tabular}




\section{Discussion}

According to the Table 1 and 2 we can see that overall the assessment has been well conducted but there is still need for some improvement in terms of its implementation. In refers to Regulation of Ministry of Culture and Education No 66 Year 2013 and The Model of Assessment in Student Competencies Achievement, the standard of authentic assessment are as follow: (1) the framework of assessment in syllabus, consists of assessment techniques and the range period for each main study materials; (2) the framework of assessment in lesson plan, consists of assessment technique, instrument, and materials; (3) developing the indicator of competency, manner, skills, and knowledge achievement; (4) manner indicators are refers to major competencies 3; (5) the indicators are formulated using the operational verbs; (6) the indicators are customized according to the related major competencies; (7) determine various assessment technique according to the manner competencies (journal, peer-assessment, selfassessment, observation), skills competencies (practice, project, and portfolio) and knowledge competencies (written test, oral test, and assignment); (8) create assessment instrument according to the assessment technique that contain achievement indicator, assessment rubric, and assessment criteria; (9) determine the scoring guidelines that contain how to do scoring and process the scores into the final score; (10) determine assessment rubric that contain guidelines/description on the scale assessment; (11) determine assessment criteria that contain achievement in the form of predicate. From those standard of assessment we can conclude that teachers have not optimally implement this assessment. In fact they are not capable enough to create optimal assessment since there are problems, such as: (1) Cannot formulate good operational verbs assessment indicators; and (2) Cannot understand how to formulate achievement indicators, assessment rubric, scoring, and assessment criteria.
Based on these constraints, some inputs that can be given to teachers are: (1) Teachers should be able to improve their knowledge to understand the use of the operational verb, formulate indicators of achievement, scoring, make assessment criteria, as well as more creative in preparing the assessment rubric; (2) Teachers should design assessment rubric at beginning of each semester, and ensure that every main competencies are already have assessment rubric; (3) Teacher should be able to do an effective assessment based on the time allocation and learning objectives; (4) Teacher should learn from other teachers to get feedbacks for their assessment plan. In regards to that assessment aspects, Jones (2005, p. 7) argued that "Planning is an essential part of a teacher's workload. Teachers need to plan and create opportunities within each session for both the learner and the teacher to obtain information about a learner's progress towards the learning goals defined by the teacher at the start of the session. It is crucial that the learning goals are communicated to the learner, and of equal importance is that the teacher checks to ensure that the learner not only understands the learning goals, but also appreciates the assessment criteria which will be used to assess the work." Assessment criteria is an important part of authentic assessment so the assessment of the student can be valid according to their capability to learn, besides assessment criteria can also reduce the subjectivity in terms of scoring, as what Wiggins (1989a, p. 711) said that "Scoring must be complex and authentic test cannot be scored on a curve, but instead are criterion-referenced, based on standards. As with formative assessment, self-assessment is central." Therefore as a teacher they need to create assessment criteria as a guidelines to assess student's achievement and process of learning.

Evaluation in this planning phase are oriented to teacher's capability to plan and prepare the manner, skills, and knowledge assessment that will be conducted at the learning process, since the authentic assess- 
ment need to be done programmatically and systematically, the implementation need to be prepared with clear and precise measurement. In authentic assessment plan, assessment criterion and the way we process the score should be thoroughly understood by the teachers. Furthermore, according to Regulation of Ministry of Culture and Education Year 2013 and The Model of Assessment in Student Competencies Achievement, the standard implementations of authentic assessment are as follow: (1) informing manner, skills, and knowledge competency that will be assess-ed; (2) informing techniques that will be applied; (3) informing assessment rubric and criteria; (4) conducting integrated manner, skills, knowledge assessment; (5) Using techniques and instruments that has been planned; (6) Conducting conducive, quite, and comfortable assessment.

One of the authentic assessment principles is to measure the competence of students in various ways and sources. That can be a source of assessment process and products Suarta, Hardika, Sanjaya, \& Arjana (2015, p. 48). Therefore, the implementation of authentic assessment in this regard depends on the ability of teachers to implement assessment methods and tools to assess the manner, skills, and knowledge of students in accordance with the competence to be achieved. The precision of the use of appropriate methods and instrument will be able to describe the actual student's competence. From that implementation standard, teachers are known have not apply the instrument properly, it can be seen from the obstacles experienced by teachers. In fact, most of teachers does not: (1) Inform their student about assessment techniques; (2) Inform assessment rubric and criteria; (3) Use planned technique and instrument, for instance teachers do not use assessment rubric as what cited in lesson plan; (4) Using all of instrument as cited in lesson plan; and (5) Most of teachers are assessing knowledge rather than other competencies.
From those problems we can suggest some feedbacks, such as: (1) Teachers should be committed to carry out the evaluation as planned and the assessment carried out consistently; (2) Teacher should carry out a thorough assessment by seeking involvement of social aspects of spiritual, attitudes, skills and knowledge, as well as the implementation of the continuous assessment to determine the development of students' abilities and carry out the followup of their development; (3) Teacher should inform students that assessment will be implemented in lesson; (4) Teacher should carry out an assessment on know-ledge, skills, and attitudes competencies in a balanced, coherent and comprehensive ways. The findings coincide with what presented by Sadler (2005) that "the success of any assessment is depending on the effective selection and use of appropriate procedures as well as on the proper interpretation of student's performance. Thus, assessment procedures also help in evaluation the suitability and effectiveness of the curriculum, the teaching methodology and the instructional materials." Thus the success of assessment depends on the effectiveness in the selection of valuation techniques and the implementation of the assessment procedure that is able to interpret valid students' ability. Therefore, in its implementation required a competent teacher who commit to implement professional and procedural assessment. Puckett \& Black (2008) defines the scope of authentic assessment, namely: "The "four P's" of authentic assessment. The four words starting with $\mathrm{P}$ that are listed as characteristics of authenticity, however, seem to describe a valid performancebased assessments in general, not what most of advocates would argue are the crucial dimensions of authentic assessment: Process, Performance, Products and Portfolios." Therefore, in the implementation phase, authentic assessment includes an assessment of how the development process of student learning, how the student's performance, and how the products produced by the students. 
Besides the planning and process phases, according to Regulation Ministry of Culture and Education No 66 Year 2013 and The Model of Assessment in Student Competencies Achievement, standard of outcome assessment are as follow: (1) process assessment result based on scoring criteria and guidelines for each assessed competencies; (2) determine the value with certain calculation and formulation; (3) compare the result of knowledge assessment with the minimum score, meanwhile the result of skills and manner assessment are determined by the achieved score using assessment rubric base; (4) create written report with numbers and described description; (5) assessment result is analyzed to know student's obstacles and development, that result is given back to the students with constructive comments; (6) write the result of assessment in numbers and/or competencies category as the documentation; (7) Conduct remedial program for those who have not met the minimum score; (8) conduct knowledge enrichment program for those who have met the minimum score. From that outcome standard, we can see that teachers are not apply this kind of assessment optimally, it implies from the obstacles and problems experienced by teachers. In fact, teachers do not do a result documentation systematically.

We are strongly recommend for teacher to have peer-discussion to enrich their knowledge in terms of the application of this authentic assessment program, so that there will be positive feedback for the students as well as their parents. Therefore, communication with their parents is really important, hence the parents will also know the developing of their children. The involvement of parents in this authentic assessment is really important, as what Frey \& Schmitt (2007, p. 11) said that "the involvement of families in the assessments parallels the role of the students in authentic assessment for school-aged children."

The results of the assessment (outcome) should be valid, comprehensive, and representative so that it can truly describe the development of student learning process. This authentic output can be used as a self-reflection for both teachers and students to keep doing improvements, so students should always know their learning development. Paris \& Ayres (1994) affirmed that "authentic assessment in terms suggesting that authenticity requires that the assessments be formative. They join some who argue that authentic assessment, Because it is formative, creates reflective students and teachers", it means that the authentic assessment is an assessment which can be used as a reflection towards a better achievement. Thus the assessment activities not only provide feedback to the students but also to teachers to continuously improve the quality of learning. It is also expressed by Black, Harrison, Lee, Marshall, \& Wiliam (2003) that "An assessment activity can help learning if It provides information to be used as feedback by teachers and their pupils in assessing Themselves and each other, to modify the teaching and learning activities in the which they are engaged. Such assessment Becomes ormative assessment when the evidence is actually used to adapt the teaching to meet learning needs." Assessment activity can help learning process if there is information to be used as feedback by teachers and their students in assessing themselves and each other so that the implementation and learning process of assessment will always carried out through the right way. That argument is supported by Hattie \& Timperley (2007) who wrote about the importance of feedback given to students, "Generally, the feedback has to be given as soon as possible after the completion of the learning task. Also students need to see that the feedforward comments can be incorporated into subsequent performance and overall influence the quality of Reviews their learning in positive ways. At the same time, in some instances, Temporarily withholding feedback is needed to allow the students to internalize and process the demands of the task." Generally, the feedback should be given as soon as possible after the comple- 
tion of the students' task to make students realize and reflect advantages and disadvantages as well as to strive better in the future.

From some of the results of an evaluation, it is known that the overall teacher has not been able to implement an authentic assessment of learning optimally since there are obstacles faced by teachers, therefore, should be efforts to provide additional information that is more specific and practical toward teachers in terms of authentic assessment and its implementation in the learning activities, hence teachers would really understand the terms and implement the assessment program professionally. Professionalism of teachers in assessing students is important, success assessments by teachers can affect student success in learning and achievement of learning goals because the result can motivate students to see their reflection in learning process. Related to these findings, Jones (2005) support by saying "Teachers of make professional judgments on learners' performance in every teaching and learning sessions undertaken from, whether consciously or subconsciously. Using professional Reviews These judgments and translating them into a feedback on the quality of individuals' work is the focus of Assessment for Learning. Successful Assessment for Learning strategies result in improved learner progress on a continual basis. The principal characteristic of Assessment for Learning is effective feedback provided by teachers to learners on their progress." Teachers should carry out a professional assessment in order to describe the capabilities and quality of students in valid way, also able to provide feedback for both students and the undertaken learning.

\section{Conclusion}

From the result, we can conclude that: The planning stage (antecendents) or understanding of the authentic assessment design is not fully fulfil the standard, it can only categorized as Good with $68.75 \%$ of percentage. Process stage (transaction) or execution gets percentage of $63.41 \%$ and also categorized as Good. Results phase (outcomes) shows $68.48 \%$, so that it also classified in Good category. Although the overall result has been running well, but of the standard that should be $100 \%$, there are several obstacles in each stages and caused the implementation cannot be run well. Therefore we need some feedbacks toward for the sake of improvement, we need some efforts to provide additional information that is more specific and practical to teachers about authentic assessment and the need for commitment and professionalism of teachers in carrying out the assessment in accordance with the terms and systematics specified on the Curriculum 2013's standard of assessment. The results of this evaluation conducted in Province of Yogyakarta shows that not all aspects met the standards of $100 \%$. Therefore, the findings of this study are expected to be used as a reflection to improve the performance of all stakeholders, especially teachers, principals, and parents to continue work together for the sake of improvement of the quality of authentic assessment in students. With coordination among all stakeholders, implementation of authentic assessment will be run more optimally.

\section{Refferences}

Alkin, M. C. (2011). Essential evaluation. New York: The Guilford Press.

Arikunto, S. (2013). Dasar-dasar evaluasi pendidikan (2nd ed.). Jakarta: Earth Literacy.

Black, P., Harrison, C., Lee, C., Marshall, B., \& Wiliam, D. (2003). Assessment for learning: putting it into practice. Buckingham: Open University Press.

Doll, R. C. (1964). Curriculum improvement: decision-making and process. Boston: Allyn and Bacon.

Fook, C. Y., \& Sidhu, G. K. (2010). Authentic assessment and pedagogical strategies in higher education. Journal of Social Sciences, 6(2), 153-161. https://doi.org/10.3844/jssp.2010.15 3.161

Frey, B. B., \& Schmitt, V. L. (2007). 
Coming to terms with classroom assessment. Journal of Advanced Academics, 18(3), 402-423. https://doi.org/10.4219/jaa-2007-495

Hattie, J., \& Timperley, H. (2007). The power of feedback. Review of Educational Research, 77(1), 81-112. https://doi.org/10.3102/00346543029 8487

Hein, G. E. (1991). Active assessment for active science. Alexandria: Association for Supervision and Curriculum Development.

Jones. (2005). Assessment for learning. London: Learning and Skills Development Agency.

Kementerian Pendidikan dan Kebudayaan. (2014). Materi pelatiban guru implementasi kurikulum 2013 Tabun 2014 SD Kelas IV. Jakarta: Kementerian Pendidikan dan Kebudayaan.

Khilmiyah, A., Sumarno, S., \& Zuchdi, D. (2015). Pengembangan model penilaian keterampilan intrapribadi dan antarpribadi dalam pendidikan karakter di sekolah dasar. Jurnal Penelitian Dan Evaluasi Pendidikan, 19(1), 1-12. https://doi.org/10.21831/pep.v19i1.4 550

Mendikbud RI. Peraturan Menteri Pendidikan dan Kebudayaan Nomor 66 Tahun 2013 tentang Standar Penilaian (2013).

Miles, M. B., Huberman, A. M., \& Saldana, J. (2014). Qualitative data analysis: a methods sourcebook (3rd ed.). New York: SAGE Publications, Inc.

Mueller, J. (2005). The authentic assessment toolbox: Enhancing student learning through online faculty development. Journal of Online Learning and Teaching, 1(1). Retrieved from http://jolt.merlot.org/documents/vol 1_no1_mueller_001.pdf

Palm, T. (2008). Authentic assessment and performance assessment: A conceptual analysis of the literature. Practical

Assessment, Research \& Evaluation, 13(4).

Retrieved from

http://pareonline.net/getvn.asp?v $=13$ $\% 26 n=4$

Paris, S. G., \& Ayres, L. R. (1994). Becoming reflective students and teachers: with portfolios and authentic assessment. Washington, D.C: American Psychological Association. Retrieved from

http://www.apa.org/pubs/books/431 6450.aspx?tab=1

Puckett, M. B., \& Black, J. K. (2008). Authentic assessment of the young child: celebrating development and learning (2nd ed.). Des Moines, IA: Prentice-Hall Inc.

Sadler, D. R. (2005). Interpretations of criteria-based assessment and grading in higher education. Assessment \& Evaluation in Higher Education, 30(2), 175-194. https://doi.org/10.1080/02602930420 00264262

Suarta, I. M., Hardika, N. S., Sanjaya, I. G. N., \& Arjana, I. W. B. (2015). Model authentic self-assessment dalam pengembangan employability skills mahasiswa pendidikan tinggi vokasi. Jurnal Penelitian Dan Evaluasi Pendidikan, 19(1), 46-57. https://doi.org/10.21831/pep.v19i1.4 555

Sukardi. (2011). Metodologi penelitian pendidikan: kompetensi dan praktiknya. Jakarta: PT. Bumi Aksara.

Sukmadinata, N. S. (2009). Pengembangan kurikulum teori dan praktik. Bandung: PT Remaja Rosdakarya.

Wiggins, G. (1989a). A true test: toward more authentic and equitable assessment. Phi Delta Kappan, 70(9), 703-713.

Wiggins, G. (1989b). Teaching to the (authentic) test. Educational Leadership, $46(7), 41-47$. 